\title{
PORTFÖY OPTIMIIZASYONUNDA
}

VERI SETLERININ VE OPTIMIZASYON

SEÇENEKLERINIIN KARŞILAŞTIRILMASI:

BİST-30 ENDEKSİ ÜZERÍNE

\section{BİR UYGULAMA}

\author{
Kutlay URUN \\ M.Sc., İstanbul Teknik Üniversitesi \\ İşletme Fakültesi \\ İşletme Mühendisliği Bölümü \\ urunkutlay@gmail.com
}

\section{Oktay TAŞ}

Prof.Dr., İstanbul Teknik Üniversitesi İsletme Fakültesi

İșletme Mühendisliği Bölümü

oktay.tas@itu.edu.tr

\section{Umut UĞURLU}

Dr.Öğr. Üyesi, Bahçeşehir Üniversitesi İktisadi İdari Sosyal Bilimler Fakültesi İşletme Bölümü umut.ugurlu@eas.bau.edu.tr

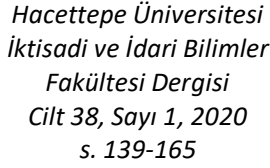

Hacettepe Üniversitesi iktisadi ve Idari Bilimler Fakültesi Dergisi Cilt 38, Sayı 1, 2020 s. $139-165$

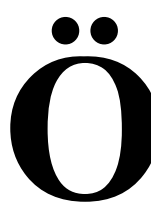

z: Bu çalışmada Türkiye'deki BİST30 endeksinde yer alan hisselerin 01/07/2015-31/12/2015, 01/01/2015$31 / 12 / 2015, \quad 01 / 01 / 2014-31 / 12 / 2015$ ve $01 / 01 / 2013-31 / 12 / 2015$ tarihleri arasındaki günlük getirilerine, Geleneksel Portföy Yöntemi temel alınarak eşit ağırlıklandırma; Modern Portföy Teorisi temel alınarak risk kısıtlı getiri maksimizasyonu, getiri kısıtlı risk minimizasyonu, direkt risk minimizasyonu ve Sharpe Oranı maksimizasyonu uygulanmaktadır. Çalışmanın amacı, birinci uygulamada, yatırımcının amaç fonksiyonuna göre hangi optimizasyon seçeneğini kullanması gerektiğini, ikinci uygulamada ise yatırımcı tipine göre hangi veri setinin kullanılması gerektiğini bulmaktır. Sonuç olarak farklı amaç fonksiyonlarında farklı optimizasyon yöntemlerini kullanmak gerektiği gibi farklı yatırımcı tiplerinde de farklı uzunluklarda veri setleri kullanılması daha iyi sonuçlar vermektedir.

Anahtar Sözcükler: Portföy optimizasyonu, performans değerlendirme, BIST-30, modern portföy teorisi. 



\title{
THE COMPARISON OF THE
}

DATASETS AND THE OPTIMIZATION

ALTERNATIVES IN THE PORTFOLIO

OPTIMIZATION: AN APPLICATION ON

\author{
Hacettepe University \\ Journal of Economics \\ and Administrative \\ Sciences \\ Vol. 38, Issue 1, 2020 \\ pp. $139-165$
}

\section{THE BIST-30 INDEX}

\section{Kutlay URUN}

M.Sc., Istanbul Technical University

Management Faculty

Management Engineering Department

urunkutlay@gmail.com

\section{Oktay TAS}

Prof.Dr., Istanbul Technical University

Management Faculty

Management Engineering Department

oktay.tas@itu.edu.tr

\section{Umut UGURLU}

Asst.Prof.Dr., Bahcesehir University

Faculty of Economics

Administrative and Social Sciences

Business Administration Department

umut.ugurlu@eas.bau.edu.tr bstract: In this research, daily returns

of the stocks in BIST-30 index of Turkey are evaluated with different $31 / 12 / 2015,01 / 01 / 2015-31 / 12 / 2015,01 / 01 / 2014$ $31 / 12 / 2015$ and $01 / 01 / 2013-31 / 12 / 2015$ by applying the equal weights method based of traditional portfolio theory; risk constrained return maximization, return constrained risk minimization, direct risk minimization and Sharpe ratio maximization, which are based on the modern porfolio theory. Firstly, according to the investor's objective function, the choice of the optimization technique is discussed. Secondly, according to the investor type, the choice of the time frame is investigated. Consequently, as different objective functions lead to the usage of different optimization methods, different type of investors need to use different term datasets to have better results.

Keywords: Portfolio optimization, performance evaluation, BIST-30, modern portfolio theory. 


\section{GíRiş}

Portföy yönetiminde ve özellikle de portföy optimizasyonunda portföyün getirisini maksimize ederken riskini de minimize etmek, finans alanında üzerinde uzun yıllardır, bir çok makale üretilen önemli bir konudur. Portföye dahil edilecek menkul kıymetlerin ağırlıklarını belirlerken, konulacak kısıtların belirlenmesi, optimizasyon seçeneklerinin hangisinin uygulanacağ 1 ve ek olarak geçmiş döneme ait veriler incelenirken ne kadar süre geriye gidilerek inceleme yapılacağı gibi konular literatürde üzerinde çalışmalar yapılan konulardan bazılarıdır. Portföy oluşturmada bir diğer konu da fayda maksimizasyonu ve yatırımcı tipine uygun portföyler oluşturmaktır. Yatırımcı tiplerine göre optimizasyon işlemlerinde, kısttlar konularak, istenen portföyler oluşturulup, gelecek dönem için test edilerek en iyi portföy seçeneği araştırlmaktadır. Ancak, örneklem kümesinin oldukça geniş olması ve ülke endekslerinin birbirinden farklı bir seyir halinde olması ile ekonomik koşulların farklılı̆̆ genel geçer bir sonuç elde edilmesini zorlaştırmaktadır.

Bu çalışmada BİST-30 endeksinin 01/07/2015 - 31/12/2015, 01/01/2015 $31 / 12 / 2015,01 / 01 / 2014$ - 31/12/2015 ve 01/01/2013 - 31/12/2015 tarihleri arasındaki günlük getirilerine, Geleneksel Portföy Yöntemi temel alınarak eşit ağırlıklandırma, Modern Portföy Teorisi temel alınarak risk kısıtlı getiri maksimizasyonu, getiri kısitlı risk minimizasyonu, direkt risk minimizasyonu ve Sharpe Oranı maksimizasyonu uygulanmaktadır. Eşit ağırlıklandırma yöntemi ile bütün hisselere eşit oranda yatırım yapıldığı durum incelenecek; risk kısıtlı getiri maksimizasyonunda riski eşit ağırlıklandırma yapılmış portföyün riskine eşit olacak şekilde bir getiri maksimizasyonu; getiri kısıtlı risk minimizasyonunda, getirisi eşit ağırlıklandırma yapılmış portföyün getirisine eşit olacak şekilde bir risk minimizasyonu; direkt risk minimizasyonunda ise eşit ağırlıklandırma yapılmış portföyün getiri ve risk değeri dikkate alınmadan direkt olarak bir risk minimizasyonu; Sharpe Oranı maksimizasyonunda, formül gereği risksiz faiz oranı bir sabit olduğu için, portföyün ortalama getiri ve standart sapması oranı maksimizasyonu uygulanarak yatırım oranları elde edilecektir.

Bu makale, portföylerini değerlendirmek ve geliştirmek isteyen yatırımcılar için, belirlenen yatırımcı profillerine göre çeşitli seçenekler sunmaktadır. Çalışmanın amacı ise, tüm bu optimizasyon seçenekleri uygulanarak elde edilen yatırım oranlarının, BİST30 endeksinin 01/01/2016 - 31/12/2016 tarihleri arasındaki günlük değerlerine uygulanarak hangi veri setine göre yapılan optimizasyonun isteneni daha iyi yerine getirdiğini, beş farklı optimizasyon seçeneğinden hangisinin belirtilen dönem için daha iyi sonuç verdiğini incelemektir. 
Makalede bu amaçla Modern Portföy Teorisi (Markowitz, 1952) kapsamında ortaya çıkan literatür dikkate alınmış olup, ortaya konan model ve yöntem, farklı veri setleri kullanılarak, farklı optimizasyon teknikleri uygulanarak test edilmiştir.

\section{LITERATÜR TARAMASI}

1950’li yıllara kadar Geleneksel Portföy Yaklaşımı, teoride ve pratikte oldukça yaygın bir şekilde kullanılmıştır. Bu yöntemin bilimsel bir temeli olmamasına rağmen, kolaylıkla uygulanabilir olmasından dolayı birçok yatırımcı tarafindan talep gören bir yöntem olmuştur (Bekçioğlu, 1984).

Geleneksel portföy yaklaşımı, aşırı çeşitlendirmeye önem vermekte olup, portföye alınması düşünülen hisse senetleri arasındaki ilişkileri dikkate almamaktadır. $\mathrm{Bu}$ yönteme göre riskin dağıtılması esas amaçtır. Portföyde yer alan yatırım araçlarının getirileri aynı yönde hareket etmeyeceğinden, portföyün riski de tek bir menkul kıymetin riskinden daha küçük olacaktır. Bu yüzden de geleneksel portföy yönetimi, portföydeki menkul kıymetlerin çeşitlendirilmesine dayanır. Bu yaklaşıma göre, farklı endüstri kollarında olan işletmelerin menkul kıymetlerinden oluşan bir çeşitlendirmeye gidilmesinin olumlu bir etki yaratacağı düşünülmektedir (Francis, 1976; Berk, 1995).

Geleneksel Portföy Yaklaşımı baz alınarak oluşturulan portföyde yer alan finansal varlıkların getirileri arasında hiçbir ilişki bulunmadığı varsayılarak yapılan çeşitlendirmeyle, önemli bir risk indirimi sağlanabilmektedir; hatta, yeterince varlık portföye dahil edilecek olursa, riskin sıfira yaklaştırılabileceği anlaşılmaktadır. Ancak bu yaklaşım tam anlamıyla doğru değildir; gerçekte tüm finansal varlık çiftleri arasındaki ilişkinin "0" olması, dolayısı ile basit çeşitlendirmeyle portföy riskinin bu denli indirilebilmesi mümkün değildir (Sharpe $v d .$, 1978; Bolak, 1998).

Geleneksel portföy yaklaşımı aşırı çeşitlendirmeye dayandığı için bir takım sakıncaları mevcuttur. Bunların başında, çok sayıda menkul değerden oluşan portföyün yönetimi oldukça güçtür; bundan ötürü bir araştırma maliyeti oluşur ki, çok sayıda yatırım aracı bulunan bir portföyde, araştırma maliyeti de oldukça yüksek olacaktır (Üstünel, 2000).

Markowitz (1952), Modern Portföy Teorisi'nin temelini atmış olup, portföy yönetimini, matematiksel ve istatistiksel açıdan anlamlı hale getirmiştir. Markowitz bu çalışmasında yatırım araçlarının getirisi ve riskini değerlendirerek optimal portföye ulaşmıştır.

Markowitz'in Ortalama - Varyans modeli, yatırımların çeşitlendirilmesinin matematiksel bir biçimde ilk ifadesidir. Yapılan bu çalışmanın en önemli özelliği, 
menkul değerlerin kendilerine ait risk değerlerinin yatırımcı için önemli olmadığıdır. Önemli olan nokta menkul değerlerin, bütün portföyün çeşitliliğine olan katkısıdır (Rubinstein, 2002).

Markowitz (1952), geleneksel portföy yaklaşımında olduğu gibi aşırı çeşitlendirmeye başvurmadan, risk ve getiri ilişkisi incelenerek de düşük riskli portföylerin oluşturulmasının mümkün olduğunu göstermiştir.

$\mathrm{N}$ adet menkul kıymet içeren bir portföyde, menkul kıymetlere değişik ağırlıklar verilerek, sınırsız sayıda portföy oluşturmak, mümkündür. Ancak burada amaç, belirli bir getiri oranında, risk değerini mümkün olduğu kadar düşürerek etkin portföyleri seçmektir. Daha önce de değinildiği gibi yatırımcı hem getiri hem de risk değerlerini göz önüne almak durumundadır. Portföydeki her bir menkul kıymetin payını ise matematiksel işlemlerle belirleyeceklerdir. Markowitz (1952), değişik risk ve getiri düzeylerindeki etkin portföyleri birleştiren eğriyi, etkin sınır olarak tanımlamıştır. Şekil 1 'de ise etkin sınır eğrisine görsel olarak bir örnek verilmiştir.

\section{Şekil 1. Etkin Sınır Ĕgrisi}

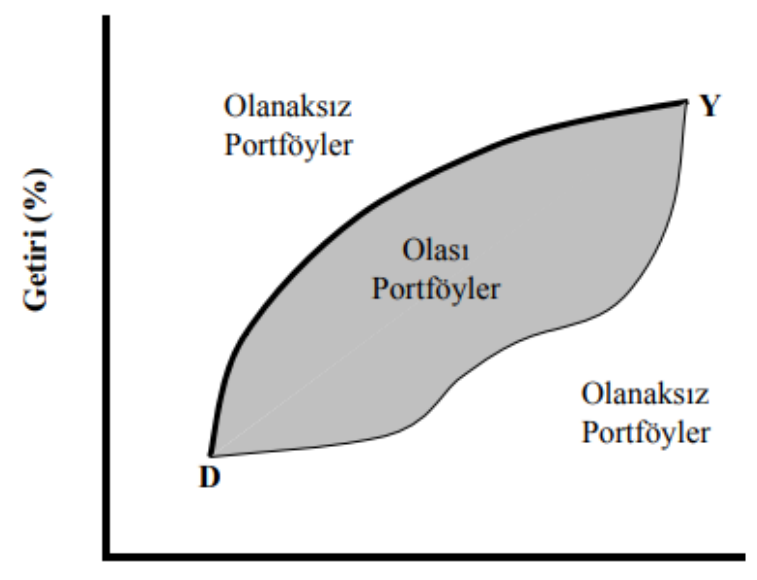

Risk (\%)

Kaynak: Bolak, 1998.

$\mathrm{N}$ adet finansal varlıktan yararlanarak oluşturulan bir portföyün beklenen getiri ve risk değerleri, aşağıdaki formüller yardımıyla hesaplanmaktadır (Bolak, 1998):

$$
E_{P}=\sum_{i=1}^{N} X_{i} E_{i}
$$


$\sigma_{P}=\left[\sum_{i=1}^{N} \sum_{j=1}^{N} X_{i} X_{j} \rho_{i, j} \sigma_{i} \sigma_{j}\right]^{1 / 2}$

$E_{P}$ : Portföyün Beklenen Getiri Değeri

$E_{i}$ : i. Hisse Senedinin Beklenen Getiri Değeri

$X_{i}:$ i. Hisse Senedinin Portföy İçerisindeki Ağırlığı

$X_{j}:$ j. Hisse Senedinin Portföy İçerisindeki Ağırlığı

$\sigma_{P}$ : Portföyün Risk Değeri

$\sigma_{i}:$ i. Hisse Senedinin Risk Değeri

$\sigma_{j}:$ j. Hisse Senedinin Risk Değeri

$\rho_{i, j}$ : i. ve j. Hisse Senetleri Arasındaki Korelasyon Katsayısı

Campbell vd. (2001), beklenen azami kaybın, risk yöneticisi tarafindan belirlenen riske maruz değer sınıını karşılaması şartıyla, beklenen getiriyi en yüksek düzeye taşımayı amaçlayan bir model üzerinde çalışmışlardır. Ortalama-varyans metodunda kullanılan Sharpe Oranına benzer bir indeks geliştirilip yapılan uygulamada, sonuçlar, birbirine oldukça benzer çıkmıştır. Buna ek olarak, Amerika Birleşik Devletleri piyasasındaki hisse senetleri ve tahviller ele alınarak yapılan çalışmada optimum portföyü elde etmek için yatırım süresinin uzunluğunun oldukça önem teşkil ettiğini gözlemlemişlerdir.

Çetin (2007), yaptığı çalışmada Markowitz kuadratik programlama ile portföy seçim modelini İMKB 30 endeksinde yer alan şirketler üzerinde incelemiştir. Çalışmada İMKB 30 şirketlerinin 03/01/2005 - 01/07/2005 tarihleri arasındaki günlük getiri değerleri baz alınmıştır. Amaç, İMKB Ulusal-30 endeksine göre oluşturulan optimal portföyün İMKB Ulusal-100, İMKB Ulusal-30 endekslerine ve eşit ağırlıklı portföye göre karşılaştırmasını yapmaktır. Standart kuadratik programlama modelini kullanarak İMKB 30 endeksi ile aynı risk düzeyinde daha yüksek getirili portföy ağırlıkları elde etmiştir. Geçmiş verilere uygulanan optimizasyondan elde edilen portföy 02/01/2006 30/06/2006 tarihleri arasındaki endeks değerlerine uygulandığında bu portföy $\% 8,6$ oranında getiri sağlarken, bu tarihler arasında İMKB-100 endeksi \%8,67; İMKB Ulusal30 endeksi $\% 9,17$; eşit ağırlıklı portföy $\% 10,82$ oranında götürüye neden olmuştur. Sonuç olarak da Markowitz'in modern portföy teorisi ve optimizasyonu IMKB'de yapılacak olan yatırımlar için uygun bir yöntemdir.

Kardiyen (2008), yaptığı çalışmada portföy teorisinin temelini oluşturan Markowitz'in ortalama-varyans modelinin kullanımında büyük boyutlu veriler 
kullanıldığında işlem zorlukları ile karşılaşılmasından dolayı Konno ve Yamazaki tarafından geliştirilen Ortalama Mutlak Sapma (MAD) modelini test etmiştir. Yapılan çalı̧̧mada, her iki model ele alınarak, bir karşılaş̧ırılma yapılmıştır. BİST-50 endeksinin Haziran 2000 - Aralık 2003 tarihleri arasındaki aylık getiri değerleri kullanılmış ve bu verilere her iki modelin uygulanması ile farklı hedef getiri düzeyleri için portföyler elde edilmiştir. BİST-50 verisi ile yapılan çalışmanın sonucunda, Markowitz'in ortalama-varyans modeli ve ortalama mutlak sapma modeli ile elde edilen portföylerin getirilerinin genelde birbirleri ile aynı ya da çok yakın değerlere sahip oldukları, Markowitz'in ortalama-varyans modeli ile elde edilen portföylerin ortalama mutlak sapma modeli ile elde edilen portföylerle ya aynı ya da daha düşük değerli varyans değerine sahip olduğu görülmüsstür.

Çetin (2009), bir başka çalışmasına İMKB-30 endeksinde yer alan şirketler üzerinde Markowitz karesel programlama yöntemini kullanarak portföy seçiminde bulunmuştur. Çalışmanın ilk aşamasında Markowitz portföy seçimi modeli, İMKB-30 endeksi ile benzer risk-getiri yapısında bir portföy oluşturacak şekle dönüştürülmüştür. Daha sonra IMKB-30 şirketlerinin Ocak 2006 - Aralık 2006 tarihleri arasındaki günlük getiri değerleri kullanılarak beklenen getiri ve varyans-kovaryans matrisi oluşturularak model çözülmüsstür. Çalışmanın ikinci aşamasında ise karesel programlama modeli kullanılarak, İMKB-30 endeksi ile eşit getiri düzeyinde, daha düşük risk değerine sahip portföy ağırlıkları ile İMKB-30 endeksi ile eşit risk düzeyinde fakat daha yüksek getiri değerine sahip portföy ağırlıkları hesaplanmıştır. 2007 ve 2008 yıllarında yaşanan küresel krizden dolayı, bu dönem İMKB için de büyük kayıpların yaşandığı bir zaman dilimi olmuştur. Hisse senetlerine eşit ağırlıkta yer veren bir portföy oluşturulması durumunda bile zararla karşılaşılmıştır. Ancak Markowitz ortalama-varyans modeli kullanılarak IMMKB-30 endeksi ile aynı getiri yapısında bir portföy oluşturulduğunda, İMKB Ulusal-30 endeksinden seçilen, farklı ağırlıklara sahip 13 adet hisse senedinin getirisi, 04/01/2007 - 13/03/2008 döneminde \%14,80; 17/03/2008 - 17/10/2008 döneminde $\% 3,48$ olmuştur. Bu optimizasyon yöntemi ile elde edilen portföyün getirisi, hem eşit ağırlıklandırma yapılmış portföyün getirisinden hem de endeks getirisinden daha yüksek çıkmıştır.

Nogales $v d$. (2009), yaptıkları çalışmada tahmin hatasını düşürmek için klasik minimum varyanslı portföy optimizasyonuna bir kısıt koyarak ilerlemişlerdir. Bu kısıt da portföylerin, ağırlık vektörlerinin, belirli bir eşikten daha düşük seviyede olmasıdır. Buna ek olarak, çalı̧̧mada çeşitli portföy stratejileri de önerilerek elde edilen sonuçlar değerlendirilmiş̧ir. Beş farklı veri setine uygulanan on farklı optimizasyon seçeneğinde elde edilen sonuçlarda, Sharpe Oranı değeri, geleneksel portföy yönteminden ve literatürdeki diğer çalışmalarda elde edilen sonuçlardan daha yüksek çıkmaktadır. 
DeMiguel $v d$. (2009), örneklem temelli ortalama-varyans modelinin performansını artırmak ve tahmini hatayı azaltmak için bir çalışma yapmışlar ve kıyas olarak eşit ağılıklandırma yapılmış portföyü baz almışlardır. ABD hisse senedi piyasasında yapılan çalışmada tamamen genel geçer yatırım tavsiyesi verilebilmesi için 25 varlıklı bir portföyde 3000 aylık verinin, 50 varlıklı bir portföyde ise 6000 aylık verinin geriye dönük olarak incelenmesi gerektiği gözlenmiştir. Bu da optimal portföyün gerçeğe tam anlamıyla uyarlanması için gidilmesi gereken çok yol olduğunu göstermektedir.

Korhan (2013), yaptığı çalı̧̧mada en az portföy optimizasyonunun önemi kadar, menkul klymetlerin ne kadarlık bir süre için geçmiş verileri dikkate alarak portföy oluşturulacağının önemini vurgulamıştır. Buna ek olarak da oluşturulan portföyün elde ne kadar tutulması gerekliliği üzerine de inceleme yapmıştır. Bu kapsamda 2006 ile 2011 yılları arasında BISST-30 endeksi içinde yer alan 24 hisse senedinin farklı geçmiş sürelerinden oluşan verileri, Markowitz ortalama-varyans modelinde kullanarak, çok sayıda portföy oluşturulmuş ve bu portföylerin elde tutulması halinde yatırım vadeleri ile geçmiş takip süreleri arasında ilişki tespit edilmiştir. Çalışmanın sonucunda, yatırımcı, eğer uzun vadeli yatırım yapmayı planlıyorsa, hisse senetlerinin kısa süreli geçmiş verilerini kullanarak portföy oluşturması, aynı şekilde yatırımcının kısa vadeli yatırım yapma düşüncesi varsa hisse senetlerinin uzun süreli geçmiş verilerinin kullanılmasının daha uygun olduğu tespit edilmiştir.

Akçayır vd. (2014), yaptığı çalışmada Elton, Gruber (1995) tarafindan geliştirilmiş olan portföy seçim yönteminin ve Markowitz'in ortalama-varyans modelinin BISST-50 endeksi üzerindeki uygulanabilirliğini test etmektedir. Uygulamada BİST-50 endeksinde işlem görmekte olan tüm hisse senetlerinin 1 Ağustos - 30 Eylül tarihleri arasındaki günlük kapanış değerleri kullanılmış ve getiriler doğal logaritma ile hesaplanmıştır. Sonuç olarak Elton-Gruber portföy seçim yöntemi ile elde edilen risk ve getiri değerleri Markowitz kuadratik programlama yöntemi için bir kısıt olarak eklendiğinde, portföylerin içinde daha etkin, yani riski daha düşük ve getirisi daha yüksek bir portföy olarak, risk ve getiri bileşeni diğerlerine benzemeyen yeni bir portföy elde edilmiştir.

Güran, Taş (2015), yaptıkları çalışmada ilk aşamada BİST-30 endeksine ikinci dereceden stokastik baskınlık testi uygulayarak, verimli olmayan hisse senetlerini, portföy dışına atıp, ikinci aşamada geriye kalan hisse senetlerine Ortalama-Varyans optimizasyonu uygulayarak iki aşamalı bir süreci gözlemlemişlerdir. Portföyler arasında Sharpe Oranının maksimize edildiği portföy seçilerek, BİST-30 portföyü ile kıyaslanmıştır. Bu iki portföyün aynı getiri oranlarına sahip olmalarına rağmen, ikinci dereceden stokastik baskınlık testi uygulanarak oluşturulan verimli portföyün riskinin, 
BİST-30 portöyünün riskinden daha büyük olduğu ve dolayısı ile de Sharpe Oranının da daha düşük olduğu tespit edilmiştir.

Taş $v d$. (2015), yaptıkları çalışmada BİST-30 ve DJIA endekslerine stokastik baskınlık testi uygulayarak, etkin hisseleri seçip, daha sonrasında bu hisselerin getirilerini hesaplamışlardır. Baskınlık testinde, zamanın önemini incelemek için veri setine eşit ağırlıklandırma, basit ağırlıklandırma ve logaritmik ağırlıklandırma uygulamışlardır. Daha sonrasında elde edilen verilere backtesting uygulanmıştır. BİST30 endeksi -\%6,01 getiri sağlarken, eşit ağırlıklandırma yöntemiyle elde edilen portföy $\% 5,28$; basit ağırlıklandırma yöntemi ile elde edilen portföy -\%6,78; logaritmik ağırlıklandırma yöntemiyle elde edilen portföy ise $-\% 5,39$ oranında getiri sağlamaktadır. Burada basit ağılıklandırma ile elde edilen portföyün getirisi, endeks getirisinin altında kalmıştır. DJIA endeksinin getirisi -\%0,70 getiri sağlarken, eşit ağırlıklandırma yöntemiyle elde edilen portföy $\% 2,12$; basit ağırlıklandırma yöntemi ile elde edilen portföy $\% 1,97$; logaritmik ağırlıklandırma yöntemiyle elde edilen portföy ise $\% 0,75$ oranında getiri sağlamaktadır. Burada bütün yöntemlerden elde edilen portföyler endeksin üzerinde bir getiri sağlamaktadır. İki endeks incelemesinde de veri setine uygulanan eşit ağırlıklandırma yöntemi, en iyi sonucu vermektedir.

\section{VERİ VE YÖNTEM}

$\mathrm{Bu}$ çalışmada Borsa İstanbul 30 (BİST-30) veri setinde bulunan hisse senetleri kullanılmıştır. Ancak PGSUS hissesinin, inceleme tarihleri içerisinde, bütün verilerinin olmaması nedeniyle inceleme 29 adet hisse üzerinden yapılacaktır. Firmaların günlük getirileri, bir önceki günkü kapanış değerine göre olan yüzdelik değişimle ifade edilmektedir. Analizlere dahil edilen 29 adet firma Tablo 1.'de gösterilmektedir.

Uygulama aşamasında BIST-30 endeksi ve endeks içerisinde yer alan hisselerin; 01/07/2015 - 31/12/2015, 01/01/2015 - 31/12/2015, 01/01/2014 - 31/12/2015 ve 01/01/2013 - 31/12/2015 tarihleri arasındaki günlük getirilerine eşit ağırlıklandırma, Ortalama - Varyans yöntemi esas alınıp getiri kısıtlı risk minimizasyonu, direkt risk minimizasyonu, risk kısıtlı getiri maksimizasyonu ve Sharpe Oranı maksimizasyonu ile hangi hisselere hangi oranda yatırım yapılması gerektiği hesaplanacaktır. Daha sonra bu yatırım oranları, 01/01/2016 - 31/12/2016 tarihleri arasındaki BISTT-30 endeks değerlerine uygulanıp bir test yapılarak, hangi dönemdeki yatırım oranlarının daha başarılı bir sonuç verdiği araştırılacaktır. Burada amaç, 1 yıl süreli yatırım için, hangi döneme ait veri setinin kullanılacağını ve hangi optimizasyon seçeneğinin daha iyi sonuç verdiğini, gözlemlemektir. 
Tablo 1. Araştırmanın Yapıldığı Döneme Ait BİST-30 Endeksi Bilgileri

\begin{tabular}{|c|c|c|c|}
\hline No & Şirket İsimleri & Sektör & Hisse Kodu \\
\hline 1 & AKBANK & Bankacilık & AKBNK \\
\hline 2 & ARÇELIK & Dayanaklı Tüketim & ARCLK \\
\hline 3 & BİM & Perakende Ticaret & BIMAS \\
\hline 4 & COCA COLA & G1da & CCOLA \\
\hline 5 & DOĞUŞ OTOMOTIV & Otomotiv & DOAS \\
\hline 6 & EMLAK KONUT & $\begin{array}{c}\text { Gayrimenkul Yatırım } \\
\text { Ortaklığ }\end{array}$ & EKGYO \\
\hline 7 & ENKA INSŞAAT & İnşaat & ENKAI \\
\hline 8 & EREĞLİ DEMIR ÇELIK & Demir Çelik & EREGL \\
\hline 9 & FORD OTOSAN & Otomotiv & FROTO \\
\hline 10 & GARANTİ BANK & Bankacılık & GARAN \\
\hline 11 & HALK BANK & Bankacilık & HALKB \\
\hline 12 & İŞ BANK & Bankacılık & ISCTR \\
\hline 13 & KOÇ HOLDİNG & Holding & $\mathrm{KCHOL}$ \\
\hline 14 & KOZA ALTIN & Demir Çelik & KOZAL \\
\hline 15 & KARDEMİR KARABÜK & Demir Çelik & KRDMD \\
\hline 16 & OTOKAR & Otomotiv & OTKAR \\
\hline 17 & PETKİM HOLDİNG & Petrokimya & PETKM \\
\hline 18 & HACI ÖMER SABANCI HOLDİNG & Holding & SAHOL \\
\hline 19 & TÜRKIYE ŞISŞE VE CAM FABRIKKALARI & Holding & SISE \\
\hline 20 & TAV HAVALIMMANLARI HOLDİNG & Ulaştırma & TAVHL \\
\hline 21 & TURKCELL İLETIŞ̧iM & Telekomünikasyon & TCELL \\
\hline 22 & TÜRK HAVA YOLLARI & Ulaştırma & THYAO \\
\hline 23 & TEKFEN HOLDİNG & Holding & TKFEN \\
\hline 24 & TOFAŞ TÜRK OTOMOBİL & Otomotiv & TOASO \\
\hline 25 & TÜRK TELEKOMÜNIKASYON & Telekomünikasyon & TTKOM \\
\hline 26 & TÜPRAŞ TÜRKIYY PETROL RAFINELERİ & Petrokimya & TUPRS \\
\hline 27 & ÜLKER & G1da & ULKER \\
\hline 28 & VAKIFLAR BANK & Bankacılık & VAKBN \\
\hline 29 & YAPI VE KREDİ BANKASI & Bankacılık & YKBNK \\
\hline
\end{tabular}

Kaynak: Yazarlar tarafindan oluşturulmuştur.

Günlük getiriler üzerinden 01/07/2015 - 31/12/2015 tarihleri arasındaki 6 aylık veri seti için yapılan incelemede 129 gözlem, 01/01/2015 - 31/12/2015 tarihleri arasındaki 1 yıllık veri seti için yapılan incelemede 253 gözlem, 01/01/2014 - 31/12/2015 tarihleri arasındaki 2 yıllık veri seti için yapılan incelemede 505 gözlem, 01/01/2013 31/12/2015 tarihleri arasındaki 3 yıllık veri seti için yapılan incelemede 754 gözlem bulunmaktadır.

Optimizasyon uygulamasına geçilmeden önce 4.1'de optimizasyon seçenekleri açıklanıp amaç ve kısıt fonksiyonları belirtilmektedir. 4.2'de BİST-30 endeksine Ortalama-Varyans optimizasyonu uygulanıp, elde edilen sonuçlar değerlendirilmektedir. 
4.3 'te, uygulanan optimizasyonlardan elde edilen portföylerin 01/01/2016 - 31/12/2016 tarihleri arasındaki performansı test edilecek ve bulgular tartışılacaktır.

\section{BULGULAR VE TARTIŞMA}

\subsection{BİST-30 Endeksine Uygulanacak Optimizasyon Seçeneklerinin Tanımı}

$\mathrm{Bu}$ bölümde, BIST-30 endeksine; eşit ağıllıklandırma, risk kısıtlı getiri maksimizasyonu, getiri kısıtlı risk minimizasyonu, direkt risk minimizasyonu ve Sharpe Oranı maksimizasyonu uygulanarak oluşturulacak portföyde, hangi hisselere hangi oranda yatırım yapılması gerektiği belirlenmektedir. Oluşturulacak portföyün getirisi, her bir hissenin ortalama getirisi ile portföydeki oranının çarpımlarının toplamıla elde edilmektedir. Portföyün riski ise 2 numaralı formülün Microsoft Excel Solver (Çözücü) uygulaması üzerinden hesaplanmasıyla bulunmaktadır.

Optimizasyon seçeneklerini tek tek açıklamadan önce hepsini tek bir grafik içerisinde Şekil 2.'de görmek mümkündür.

\section{Şekil 2. Optimizasyon Seçeneklerinin Etkin Sınır Eğrisinde Gösterimi}

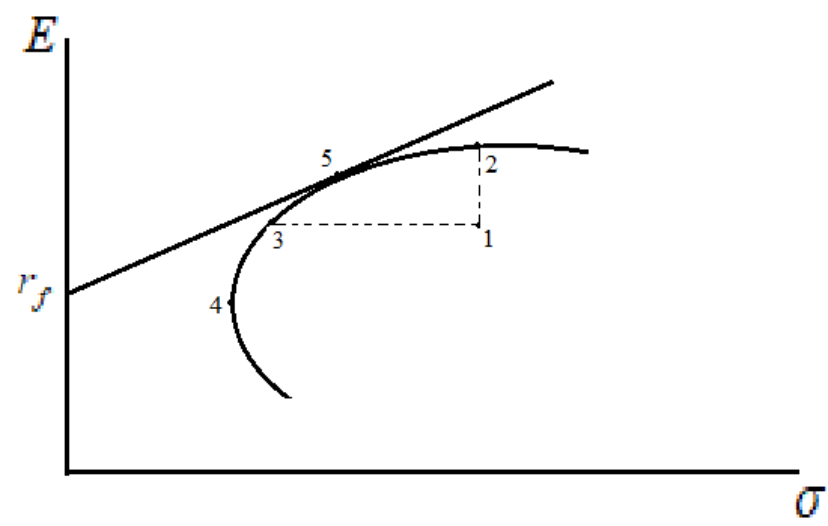

Kaynak: Bolak, 1998.

Şekil 2'ye göre 1 numaralı portföy, rastgele konumlandırılmış olup, her bir hisseye eşit ağırlıklandırma yapılmış portföyü; 2 numaralı portföy, riski eşit ağırlıklandırma yapılmış portföyün riskine eşit olacak şekilde getirisi maksimize edilmiş portföyü; 3 numaralı portföy, getirisi eşit ağırlıklandırma yapılmış portföyün getirisine eşit olacak şekilde riski minimize edilmiş portföyü; 4 numaralı portföy, herhangi bir kısıt uygulanmadan, riski minimize edilmiş portföyü ve son olarak 5 numaralı portföy de Sharpe Oranı maksimize edilmiş portföyü temsil etmektedir. Pratikte çok daha farklı 
URUN, TAŞ, UĞURLU| The Comparison of the Datasets and the Optimization Alternatives in the Portfolio..

kısıtlarla portföy kurma imkanı bulunmakla birlikte bu uygulamada, yukarıda tanımlanan portföyler arasında karşılaştırma yapılması amaçlanmıştır.

\subsubsection{Eşit Ağırlıklandırma Yöntemi}

$\mathrm{Bu}$ yöntem geleneksel portföy teorisini temel almaktadır. Portföy içerisinde bütün hisselerin eşit oranda yer aldığı ve buna göre aslında diğer optimizasyon seçeneklerinde, referans değer olacak getiri ve risk değerleri, bu aşamada elde edilmektedir.

\subsubsection{Risk Kısıtlı Getiri Maksimizasyonu}

Risk değeri, eşit ağırlıklandırma yapılmış portföyün risk değerine eşit olacak şekilde portföyün getirisinin maksimize edildiği bir optimizasyon seçeneğidir. Burada kisit denklemleri;

$$
\begin{aligned}
& X_{i} \geq 0 \\
& \sum X_{i}=1 \\
& \sigma_{P}=\sigma_{E A}
\end{aligned}
$$

Amaç fonksiyonu ise;

$$
Z_{\max }=\mu_{P}
$$

$X_{i}:$ i. hisseye portföy içerisinde verilecek ağırlık.

$\sigma_{P}$ : Portföyün standart sapma değeri.

$\sigma_{E A}$ : Eşit ağırlıklandırma yöntemi uygulanmış portföyün standart sapma değeri.

$\mu_{P}$ : Portföyün getiri değeri.

\subsubsection{Getiri Kısıtlı Risk Minimizasyonu}

Getiri değeri, eşit ağırlıklandırma yapılmış portföyün getiri değerine eşit olacak şekilde, portföyün riskinin minimize edildiği bir optimizasyon seçeneğidir. Burada kısıt denklemleri;

$$
\begin{aligned}
& X_{i} \geq 0 \\
& \sum X_{i}=1 \\
& \mu_{P}=\mu_{E A}
\end{aligned}
$$

Amaç fonksiyonu ise;

$$
Z_{\min }=\sigma_{P}
$$


$X_{i}:$ i. hisseye portföy içerisinde verilecek ağırlık.

$\mu_{P}$ : Portföyün getiri değeri.

$\mu_{E A}$ : Eşit ağırlıklandırma yöntemi uygulanmış portföyün getiri değeri.

$\sigma_{P}$ : Portföyün risk değeri.

\subsubsection{Direkt Risk Minimizasyonu}

Burada eşit ağırlıklandırma yapılmış portföyün, risk ve getiri değerlerinden herhangi biri referans olarak alınmadan oluşturulacak portföyün, riski minimize edilmektedir. Burada kısit denklemleri;

$$
\begin{aligned}
& X_{i} \geq 0 \\
& \sum X_{i}=1
\end{aligned}
$$

Amaç fonksiyonu ise;

$$
Z_{\min }=\sigma_{P}
$$

$X_{i}:$ i. hisseye portföy içerisinde verilecek ağırlık.

$\sigma_{P}:$ Portföyün risk değeri.

\subsubsection{Sharpe Oranı Maksimizasyonu}

Burada eşit ağırlıklandırma yapılmış portföyün risk ve getiri değerlerinden herhangi biri referans olarak alınmadan oluşturulacak portföyün Sharpe Oranı, maksimize edilmektedir. Burada risksiz getiri oranı hesaplanırken 1 yıl vadeli devlet tahvilinin günlük getirileri kullanılmaktadır. Burada kısıt denklemleri;

$$
\begin{aligned}
& X_{i} \geq 0 \\
& \sum X_{i}=1
\end{aligned}
$$

Amaç fonksiyonu ise;

$$
Z_{\max }=S O_{p}
$$

$X_{i}:$ i. hisseye portföy içerisinde verilecek ağırlık.

$S O_{p}$ : Portföyün Sharpe Oranı değeri.

\subsection{BíST-30 Endeksine Belirtilen Optimizasyonların Uygulanması}


$\mathrm{Bu}$ bölümde, önceki başlikta bahsedilen optimizasyon seçenekleri, BİST-30 endeksinin 01/07/2015 - 31/12/2015, 01/01/2015 - 31/12/2015, 01/01/2014 $31 / 12 / 2015$ ve 01/01/2013 - 31/12/2015 tarihleri arasındaki günlük getiri değerlerine uygulanmaktadır.

Buradan itibaren aşağıdaki kısaltmalardan faydalanılacaktır.

- Eşit ağırlıklandırma yöntemi; EA,

- Risk kısıtlı getiri maksimizasyonu; RKGM,

- Getiri k1sitlı risk minimizasyonu; GKRM

- Direkt risk minimizasyonu; DRM

- Sharpe Oranı maksimizasyonu SOM ifadeleri ile gösterilecektir.

BİST-30 endeksinin 01/07/2015 - 31/12/2015 tarihleri arasındaki günlük getirilerine uygulanan Ortalama-Varyans optimizasyonundan elde edilen yatırım oranları Tablo 2.'deki gibidir.

EA yöntemi ile portföyün riski, en düşük seviyede tutulabilse de ortalama getirisi negatif bir değer almaktadır. Ancak GKRM'de, aynı seviyede getiri düzeyi için, daha düşük risk seviyesinde bir portföy oluşturulmaktadır. Buna ek olarak DRM uygulanarak hem portföyün getirisi biraz daha iyileştirilmiş hem de risk seviyesi biraz daha aşağıya çekilmiştir. Son olarak da RKGM uygulanarak riski eşit ağırlıklandırma yapılmış portföyün risk değerine eşit olup, getirisi çok daha yüksek bir portföy elde edilmiştir. RKGM'de ve SOM'da aynı hisselere yer verilmektedir ancak kısıtlardan dolayı yatırım oranları birbirlerinden küçük farklılık göstermektedir. 
Portföy Optimizasyonunda veri Setlerinin ve Optimizasyon Seçeneklerinin... | URUN, TAŞ, UĞURLU

Tablo 2. BİST-30 Endeksinin 01/07/2015 - 31/12/2015 Tarihleri Arasındaki

Günlük Getirilerine Uygulanan Ortalama-Varyans Optimizasyonu Sonuçları

\begin{tabular}{|c|c|c|c|c|c|}
\hline & EA & RKGM & GKRM & DRM & SOM \\
\hline Kısıtlı Değiş ken & Yok & $\sigma=$ & $\mu=$ & Yok & Yok \\
\hline \multirow[t]{2}{*}{ Değişkenin Değeri } & Yok & 0.01426172 & -0.00099798 & Yok & Yok \\
\hline & \multicolumn{5}{|c|}{ Hisselerin Portföy İçerisindeki Oranları } \\
\hline AKBNK & $3.45 \%$ & $0.00 \%$ & $0.00 \%$ & $0.00 \%$ & $0.00 \%$ \\
\hline ARCLK & $3.45 \%$ & $0.00 \%$ & $0.00 \%$ & $0.00 \%$ & $0.00 \%$ \\
\hline BIMAS & $3.45 \%$ & $10.46 \%$ & $15.76 \%$ & $31.09 \%$ & $22.80 \%$ \\
\hline CCOLA & $3.45 \%$ & $0.00 \%$ & $5.80 \%$ & $3.19 \%$ & $0.00 \%$ \\
\hline DOAS & $3.45 \%$ & $0.00 \%$ & $0.00 \%$ & $0.00 \%$ & $0.00 \%$ \\
\hline EKGYO & $3.45 \%$ & $0.00 \%$ & $0.00 \%$ & $0.00 \%$ & $0.00 \%$ \\
\hline ENKAI & $3.45 \%$ & $0.00 \%$ & $26.34 \%$ & $23.08 \%$ & $0.00 \%$ \\
\hline EREGL & $3.45 \%$ & $0.00 \%$ & $3.34 \%$ & $0.00 \%$ & $0.00 \%$ \\
\hline FROTO & $3.45 \%$ & $0.00 \%$ & $4.31 \%$ & $0.00 \%$ & $0.00 \%$ \\
\hline GARAN & $3.45 \%$ & $0.00 \%$ & $0.00 \%$ & $0.00 \%$ & $0.00 \%$ \\
\hline HALKB & $3.45 \%$ & $0.00 \%$ & $0.00 \%$ & $0.00 \%$ & $0.00 \%$ \\
\hline ISCTR & $3.45 \%$ & $0.00 \%$ & $0.00 \%$ & $0.00 \%$ & $0.00 \%$ \\
\hline KCHOL & $3.45 \%$ & $0.00 \%$ & $0.00 \%$ & $0.00 \%$ & $0.00 \%$ \\
\hline KOZAL & $3.45 \%$ & $0.00 \%$ & $0.58 \%$ & $0.00 \%$ & $0.00 \%$ \\
\hline KRDMD & $3.45 \%$ & $0.00 \%$ & $0.00 \%$ & $0.00 \%$ & $0.00 \%$ \\
\hline OTKAR & $3.45 \%$ & $0.00 \%$ & $2.02 \%$ & $8.42 \%$ & $0.00 \%$ \\
\hline PETKM & $3.45 \%$ & $89.54 \%$ & $0.00 \%$ & $8.08 \%$ & $77.20 \%$ \\
\hline SAHOL & $3.45 \%$ & $0.00 \%$ & $0.00 \%$ & $0.00 \%$ & $0.00 \%$ \\
\hline SISE & $3.45 \%$ & $0.00 \%$ & $0.00 \%$ & $0.00 \%$ & $0.00 \%$ \\
\hline TAVHL & $3.45 \%$ & $0.00 \%$ & $13.46 \%$ & $8.68 \%$ & $0.00 \%$ \\
\hline TCELL & $3.45 \%$ & $0.00 \%$ & $9.13 \%$ & $3.08 \%$ & $0.00 \%$ \\
\hline THYAO & $3.45 \%$ & $0.00 \%$ & $0.00 \%$ & $0.00 \%$ & $0.00 \%$ \\
\hline TKFEN & $3.45 \%$ & $0.00 \%$ & $0.00 \%$ & $0.00 \%$ & $0.00 \%$ \\
\hline TOASO & $3.45 \%$ & $0.00 \%$ & $0.00 \%$ & $0.00 \%$ & $0.00 \%$ \\
\hline TTКОМ & $3.45 \%$ & $0.00 \%$ & $17.09 \%$ & $10.48 \%$ & $0.00 \%$ \\
\hline TUPRS & $3.45 \%$ & $0.00 \%$ & $0.00 \%$ & $1.65 \%$ & $0.00 \%$ \\
\hline ULKER & $3.45 \%$ & $0.00 \%$ & $2.18 \%$ & $2.23 \%$ & $0.00 \%$ \\
\hline VAKBN & $3.45 \%$ & $0.00 \%$ & $0.00 \%$ & $0.00 \%$ & $0.00 \%$ \\
\hline YKBNK & $3.45 \%$ & $0.00 \%$ & $0.00 \%$ & $0.00 \%$ & $0.00 \%$ \\
\hline$\sum \mathbf{w}_{\mathbf{i}}$ & $100 \%$ & $100 \%$ & $100 \%$ & $100 \%$ & $100 \%$ \\
\hline$\mu$ & -0.00099798 & 0.00104290 & -0.00099798 & -0.00025398 & 0.00098425 \\
\hline$\Sigma$ & 0.01426172 & 0.01426173 & 0.01107354 & 0.01062957 & 0.01336693 \\
\hline Sharpe Oranı & -0.08961903 & 0.05348325 & -0.11542122 & -0.05024809 & 0.05267583 \\
\hline
\end{tabular}

Kaynak: Yazarlar tarafindan oluşturulmuştur. 
URUN, TAŞ, UĞURLU| The Comparison of the Datasets and the Optimization Alternatives in the Portfolio...

BİST-30 endeksinin 01/01/2015 - 31/12/2015 tarihleri arasındaki günlük getirilerine uygulanan Ortalama-Varyans optimizasyonundan elde edilen yatırım oranları Tablo 3.'teki gibidir.

Tablo 3. BİST-30 Endeksinin 01/01/2015 - 31/12/2015 Tarihleri Arasındaki Günlük Getirilerine Uygulanan Ortalama-Varyans Optimizasyonu Sonuçları

\begin{tabular}{|c|c|c|c|c|c|}
\hline & EA & RKGM & GKRM & DRM & SOM \\
\hline Kısıtlı Değișken & Yok & $\sigma=$ & $\mu=$ & Yok & Yok \\
\hline \multirow{2}{*}{ Değişkenin Değeri } & Yok & 0.01349571 & -0.00033150 & Yok & Yok \\
\hline & \multicolumn{5}{|c|}{ Hisselerin Portföy İçerisindeki Oranları } \\
\hline AKBNK & $3.45 \%$ & $0.00 \%$ & $0.00 \%$ & $0.00 \%$ & $0.00 \%$ \\
\hline ARCLK & $3.45 \%$ & $0.00 \%$ & $6.63 \%$ & $8.08 \%$ & $0.00 \%$ \\
\hline BIMAS & $3.45 \%$ & $0.00 \%$ & $14.81 \%$ & $18.08 \%$ & $0.00 \%$ \\
\hline CCOLA & $3.45 \%$ & $0.00 \%$ & $11.07 \%$ & $5.99 \%$ & $0.00 \%$ \\
\hline DOAS & $3.45 \%$ & $0.00 \%$ & $0.00 \%$ & $0.00 \%$ & $0.00 \%$ \\
\hline EKGYO & $3.45 \%$ & $0.00 \%$ & $0.00 \%$ & $0.00 \%$ & $0.00 \%$ \\
\hline ENKAI & $3.45 \%$ & $0.00 \%$ & $22.00 \%$ & $22.21 \%$ & $0.00 \%$ \\
\hline EREGL & $3.45 \%$ & $0.00 \%$ & $3.36 \%$ & $0.00 \%$ & $0.00 \%$ \\
\hline FROTO & $3.45 \%$ & $0.00 \%$ & $0.00 \%$ & $0.00 \%$ & $0.00 \%$ \\
\hline GARAN & $3.45 \%$ & $0.00 \%$ & $0.00 \%$ & $0.00 \%$ & $0.00 \%$ \\
\hline HALKB & $3.45 \%$ & $0.00 \%$ & $0.00 \%$ & $0.00 \%$ & $0.00 \%$ \\
\hline ISCTR & $3.45 \%$ & $0.00 \%$ & $0.00 \%$ & $0.00 \%$ & $0.00 \%$ \\
\hline KCHOL & $3.45 \%$ & $0.00 \%$ & $0.00 \%$ & $0.00 \%$ & $0.00 \%$ \\
\hline KOZAL & $3.45 \%$ & $0.00 \%$ & $0.00 \%$ & $0.00 \%$ & $0.00 \%$ \\
\hline KRDMD & $3.45 \%$ & $0.00 \%$ & $0.00 \%$ & $0.00 \%$ & $0.00 \%$ \\
\hline OTKAR & $3.45 \%$ & $2.56 \%$ & $0.00 \%$ & $0.00 \%$ & $0.00 \%$ \\
\hline PETKM & $3.45 \%$ & $27.43 \%$ & $1.35 \%$ & $11.75 \%$ & $18.51 \%$ \\
\hline SAHOL & $3.45 \%$ & $0.00 \%$ & $0.00 \%$ & $0.00 \%$ & $0.00 \%$ \\
\hline SISE & $3.45 \%$ & $0.00 \%$ & $0.00 \%$ & $0.00 \%$ & $0.00 \%$ \\
\hline TAVHL & $3.45 \%$ & $0.00 \%$ & $7.43 \%$ & $9.64 \%$ & $0.00 \%$ \\
\hline TCELL & $3.45 \%$ & $0.00 \%$ & $12.14 \%$ & $9.36 \%$ & $0.00 \%$ \\
\hline THYAO & $3.45 \%$ & $0.00 \%$ & $0.00 \%$ & $0.00 \%$ & $0.00 \%$ \\
\hline TKFEN & $3.45 \%$ & $0.00 \%$ & $8.62 \%$ & $2.74 \%$ & $0.00 \%$ \\
\hline TOASO & $3.45 \%$ & $30.15 \%$ & $0.00 \%$ & $0.00 \%$ & $36.13 \%$ \\
\hline TTKOM & $3.45 \%$ & $0.00 \%$ & $7.91 \%$ & $6.31 \%$ & $0.00 \%$ \\
\hline TUPRS & $3.45 \%$ & $39.87 \%$ & $0.00 \%$ & $0.00 \%$ & $45.37 \%$ \\
\hline ULKER & $3.45 \%$ & $0.00 \%$ & $4.68 \%$ & $5.86 \%$ & $0.00 \%$ \\
\hline VAKBN & $3.45 \%$ & $0.00 \%$ & $0.00 \%$ & $0.00 \%$ & $0.00 \%$ \\
\hline YKBNK & $3.45 \%$ & $0.00 \%$ & $0.00 \%$ & $0.00 \%$ & $0.00 \%$ \\
\hline$\sum \mathbf{w}_{\mathbf{i}}$ & $100 \%$ & $100 \%$ & $100 \%$ & $100 \%$ & $100 \%$ \\
\hline$\mu$ & -0.00033150 & 0.00097755 & -0.00033150 & -0.00005898 & 0.00102674 \\
\hline$\Sigma$ & 0.01349571 & 0.01349671 & 0.01047073 & 0.01032821 & 0.01405953 \\
\hline Sharpe Oranı & -0.04407440 & 0.05291867 & -0.05680747 & -0.03120544 & 0.05429928 \\
\hline
\end{tabular}

Kaynak: Yazarlar tarafindan oluşturulmuştur. 
EA yöntemi ile portföyün riski en düşük seviyede tutulabilse de ortalama getirisi negatif bir değer almaktadır. Ancak GKRM aynı seviyede getiri düzeyi için daha düşük risk seviyesinde bir portföy oluşturulmaktadır. Buna ek olarak DRM uygulanarak hem portföyün getirisi biraz daha iyileştirilmiş hem de risk seviyesi biraz daha aşağıya çekilmiştir. Son olarak da RKGM uygulanarak riski eşit ağırlıklandırma yapılmış portföyün risk değerine eşit olup, getirisi çok daha yüksek bir portföy elde edilmiştir. RKGM'de ve SOM'da OTKAR hissesi hariç aynı hisselere yer verilmektedir ancak kısıtlardan dolayı yatırım oranları birbirlerinden küçük farklı1ık göstermektedir.

BİST-30 endeksinin 01/01/2014 - 31/12/2015 tarihleri arasındaki günlük getirilerine uygulanan Ortalama-Varyans optimizasyonundan elde edilen yatırım oranları Tablo 4.'teki gibidir.

EA yöntemi ile portföyün riski düşük seviyede tutulabilse de GKRM'de aynı seviyede getiri düzeyi için daha düşük risk seviyesinde bir portföy oluşturulmaktadır. Buna ek olarak RKGM uygulanarak riski EA yapılmış portföyün risk değerine eşit, getirisi iyileştirilmiş bir portföy elde etmek mümkündür. RKGM'de ve SOM'da BIMAS ve FROTO hisseleri hariç aynı hisselere yer verilmektedir; ancak, kısıtlardan dolayı yatırım oranları birbirinden farklılık göstermektedir. 
URUN, TAŞ, UĞURLU| The Comparison of the Datasets and the Optimization Alternatives in the Portfolio...

Tablo 4. BİST-30 Endeksinin 01/01/2014 - 31/12/2015 Tarihleri Arasındaki

Günlük Getirilerine Uygulanan Ortalama-Varyans Optimizasyonu Sonuçları

\begin{tabular}{|c|c|c|c|c|c|}
\hline & EA & RKGM & GKRM & DRM & SOM \\
\hline Kısıtlı Değişken & Yok & $\sigma=$ & $\mu=$ & Yok & Yok \\
\hline \multirow[t]{2}{*}{ Değişkenin Değeri } & Yok & 0.01292955 & 0.00048338 & Yok & Yok \\
\hline & \multicolumn{5}{|c|}{ Hisselerin Portföy İçerisindeki Oranları } \\
\hline AKBNK & $3.45 \%$ & $0.00 \%$ & $0.00 \%$ & $0.00 \%$ & $0.00 \%$ \\
\hline ARCLK & $3.45 \%$ & $0.00 \%$ & $3.83 \%$ & $4.07 \%$ & $0.00 \%$ \\
\hline BIMAS & $3.45 \%$ & $2.06 \%$ & $15.06 \%$ & $14.99 \%$ & $0.00 \%$ \\
\hline CCOLA & $3.45 \%$ & $0.00 \%$ & $5.06 \%$ & $8.70 \%$ & $0.00 \%$ \\
\hline DOAS & $3.45 \%$ & $13.21 \%$ & $0.00 \%$ & $0.00 \%$ & $18.07 \%$ \\
\hline EKGYO & $3.45 \%$ & $0.00 \%$ & $0.00 \%$ & $0.00 \%$ & $0.00 \%$ \\
\hline ENKAI & $3.45 \%$ & $0.00 \%$ & $11.44 \%$ & $12.88 \%$ & $0.00 \%$ \\
\hline EREGL & $3.45 \%$ & $16.90 \%$ & $10.49 \%$ & $8.54 \%$ & $13.45 \%$ \\
\hline FROTO & $3.45 \%$ & $0.43 \%$ & $4.81 \%$ & $3.70 \%$ & $0.00 \%$ \\
\hline GARAN & $3.45 \%$ & $0.00 \%$ & $0.00 \%$ & $0.00 \%$ & $0.00 \%$ \\
\hline HALKB & $3.45 \%$ & $0.00 \%$ & $0.00 \%$ & $0.00 \%$ & $0.00 \%$ \\
\hline ISCTR & $3.45 \%$ & $0.00 \%$ & $0.00 \%$ & $0.00 \%$ & $0.00 \%$ \\
\hline KCHOL & $3.45 \%$ & $0.00 \%$ & $3.27 \%$ & $2.54 \%$ & $0.00 \%$ \\
\hline KOZAL & $3.45 \%$ & $0.00 \%$ & $1.07 \%$ & $1.81 \%$ & $0.00 \%$ \\
\hline KRDMD & $3.45 \%$ & $0.00 \%$ & $0.00 \%$ & $0.00 \%$ & $0.00 \%$ \\
\hline OTKAR & $3.45 \%$ & $21.08 \%$ & $3.60 \%$ & $1.55 \%$ & $24.76 \%$ \\
\hline PETKM & $3.45 \%$ & $0.00 \%$ & $1.99 \%$ & $1.75 \%$ & $0.00 \%$ \\
\hline SAHOL & $3.45 \%$ & $0.00 \%$ & $0.00 \%$ & $0.00 \%$ & $0.00 \%$ \\
\hline SISE & $3.45 \%$ & $0.00 \%$ & $0.00 \%$ & $0.00 \%$ & $0.00 \%$ \\
\hline TAVHL & $3.45 \%$ & $8.41 \%$ & $7.78 \%$ & $7.18 \%$ & $3.18 \%$ \\
\hline TCELL & $3.45 \%$ & $0.00 \%$ & $13.52 \%$ & $15.20 \%$ & $0.00 \%$ \\
\hline THYAO & $3.45 \%$ & $0.00 \%$ & $0.00 \%$ & $0.00 \%$ & $0.00 \%$ \\
\hline TKFEN & $3.45 \%$ & $0.00 \%$ & $0.00 \%$ & $0.95 \%$ & $0.00 \%$ \\
\hline TOASO & $3.45 \%$ & $7.36 \%$ & $0.00 \%$ & $0.00 \%$ & $7.20 \%$ \\
\hline TTКОМ & $3.45 \%$ & $0.00 \%$ & $4.84 \%$ & $5.96 \%$ & $0.00 \%$ \\
\hline TUPRS & $3.45 \%$ & $30.54 \%$ & $6.63 \%$ & $3.58 \%$ & $33.34 \%$ \\
\hline ULKER & $3.45 \%$ & $0.00 \%$ & $6.61 \%$ & $6.62 \%$ & $0.00 \%$ \\
\hline VAKBN & $3.45 \%$ & $0.00 \%$ & $0.00 \%$ & $0.00 \%$ & $0.00 \%$ \\
\hline YKBNK & $3.45 \%$ & $0.00 \%$ & $0.00 \%$ & $0.00 \%$ & $0.00 \%$ \\
\hline$\sum \mathbf{w}_{\mathbf{i}}$ & $100 \%$ & $100 \%$ & $100 \%$ & $100 \%$ & $100 \%$ \\
\hline$\mu$ & 0.00048338 & 0.00117789 & 0.00048338 & 0.00036894 & 0.00126806 \\
\hline$\Sigma$ & 0.01292955 & 0.01293055 & 0.01020807 & 0.01016314 & 0.01377179 \\
\hline Sharpe Oranı & 0.01739125 & 0.07110049 & 0.02202777 & 0.01086436 & 0.07330501 \\
\hline
\end{tabular}

Kaynak: Yazarlar tarafindan oluşturulmuştur. 
Portföy Optimizasyonunda veri Setlerinin ve Optimizasyon Seçeneklerinin... | URUN, TAŞ, UĞURLU

BİST-30 endeksinin 01/01/2013 - 31/12/2015 tarihleri arasındaki günlük getirilerine uygulanan Ortalama-Varyans optimizasyonundan elde edilen yatırım oranları Tablo 5.'teki gibidir.

Tablo 5. BİST-30 Endeksinin 01/01/2013 - 31/12/2015 Tarihleri Arasındaki Günlük Getirilerine Uygulanan Ortalama-Varyans Optimizasyonu Sonuçları

\begin{tabular}{|c|c|c|c|c|c|}
\hline & EA & RKGM & GKRM & DRM & SOM \\
\hline Kısıtlı Değişken & Yok & $\sigma=$ & $\mu=$ & Yok & Yok \\
\hline \multirow[t]{2}{*}{ Değişkenin Değeri } & Yok & 0.01509761 & 0.00027535 & Yok & Yok \\
\hline & \multicolumn{5}{|c|}{ Hisselerin Portföy İçerisindeki Oranları } \\
\hline AKBNK & $3.45 \%$ & $0.00 \%$ & $0.00 \%$ & $0.00 \%$ & $0.00 \%$ \\
\hline ARCLK & $3.45 \%$ & $0.00 \%$ & $1.26 \%$ & $1.31 \%$ & $0.00 \%$ \\
\hline BIMAS & $3.45 \%$ & $1.35 \%$ & $14.17 \%$ & $14.14 \%$ & $0.00 \%$ \\
\hline CCOLA & $3.45 \%$ & $0.00 \%$ & $8.22 \%$ & $8.16 \%$ & $0.00 \%$ \\
\hline DOAS & $3.45 \%$ & $0.00 \%$ & $0.00 \%$ & $0.00 \%$ & $0.00 \%$ \\
\hline EKGYO & $3.45 \%$ & $0.00 \%$ & $0.00 \%$ & $0.00 \%$ & $0.00 \%$ \\
\hline ENKAI & $3.45 \%$ & $0.21 \%$ & $15.28 \%$ & $15.20 \%$ & $0.00 \%$ \\
\hline EREGL & $3.45 \%$ & $19.48 \%$ & $11.37 \%$ & $11.51 \%$ & $7.86 \%$ \\
\hline FROTO & $3.45 \%$ & $2.58 \%$ & $0.00 \%$ & $0.00 \%$ & $0.00 \%$ \\
\hline GARAN & $3.45 \%$ & $0.00 \%$ & $0.00 \%$ & $0.00 \%$ & $0.00 \%$ \\
\hline HALKB & $3.45 \%$ & $0.00 \%$ & $0.00 \%$ & $0.00 \%$ & $0.00 \%$ \\
\hline ISCTR & $3.45 \%$ & $0.00 \%$ & $0.00 \%$ & $0.00 \%$ & $0.00 \%$ \\
\hline KCHOL & $3.45 \%$ & $0.00 \%$ & $0.00 \%$ & $0.00 \%$ & $0.00 \%$ \\
\hline KOZAL & $3.45 \%$ & $0.00 \%$ & $1.92 \%$ & $1.74 \%$ & $0.00 \%$ \\
\hline KRDMD & $3.45 \%$ & $0.00 \%$ & $0.00 \%$ & $0.00 \%$ & $0.00 \%$ \\
\hline OTKAR & $3.45 \%$ & $14.17 \%$ & $0.00 \%$ & $0.00 \%$ & $23.47 \%$ \\
\hline PETKM & $3.45 \%$ & $0.17 \%$ & $4.48 \%$ & $4.52 \%$ & $0.00 \%$ \\
\hline SAHOL & $3.45 \%$ & $0.00 \%$ & $0.00 \%$ & $0.00 \%$ & $0.00 \%$ \\
\hline SISE & $3.45 \%$ & $0.00 \%$ & $0.00 \%$ & $0.00 \%$ & $0.00 \%$ \\
\hline TAVHL & $3.45 \%$ & $22.27 \%$ & $1.48 \%$ & $1.69 \%$ & $30.28 \%$ \\
\hline TCELL & $3.45 \%$ & $0.00 \%$ & $21.14 \%$ & $20.93 \%$ & $0.00 \%$ \\
\hline THYAO & $3.45 \%$ & $0.00 \%$ & $0.00 \%$ & $0.00 \%$ & $0.00 \%$ \\
\hline TKFEN & $3.45 \%$ & $0.00 \%$ & $0.00 \%$ & $0.00 \%$ & $0.00 \%$ \\
\hline TOASO & $3.45 \%$ & $6.73 \%$ & $0.00 \%$ & $0.00 \%$ & $12.88 \%$ \\
\hline TTKOM & $3.45 \%$ & $0.00 \%$ & $8.61 \%$ & $8.39 \%$ & $0.00 \%$ \\
\hline TUPRS & $3.45 \%$ & $8.77 \%$ & $4.23 \%$ & $4.38 \%$ & $0.00 \%$ \\
\hline ULKER & $3.45 \%$ & $24.27 \%$ & $7.83 \%$ & $8.02 \%$ & $25.51 \%$ \\
\hline VAKBN & $3.45 \%$ & $0.00 \%$ & $0.00 \%$ & $0.00 \%$ & $0.00 \%$ \\
\hline YKBNK & $3.45 \%$ & $0.00 \%$ & $0.00 \%$ & $0.00 \%$ & $0.00 \%$ \\
\hline$\sum \mathbf{w}_{\mathbf{i}}$ & $100 \%$ & $100 \%$ & $100 \%$ & $100 \%$ & $100 \%$ \\
\hline $\boldsymbol{\mu}$ & 0.00027535 & 0.00098921 & 0.00027435 & 0.00028313 & 0.00113739 \\
\hline$\Sigma$ & 0.01509761 & 0.01509861 & 0.01195290 & 0.01195248 & 0.01678161 \\
\hline Sharpe Oranı & 0.00249028 & 0.04977028 & 0.00306179 & 0.00379681 & 0.05360840 \\
\hline
\end{tabular}

Kaynak: Yazarlar tarafindan oluşturulmuştur. 
EA yöntemi ile portföyün riski düşük seviyede tutulabilse de GKRM'de aynı seviyede getiri düzeyi için daha düşük risk seviyesinde bir portföy oluşturulmaktadır. Buna ek olarak RKGM uygulanarak riski eşit ağırlıklandırma yapılmış portföyün risk değerine eşit, getirisi iyileştirilmiş bir portföy elde etmek mümkündür.

\subsection{Bulguların Test Edilmesi ve Değerlendirilmesi}

$\mathrm{Bu}$ bölümde, geçmiş döneme ait 4 farklı veri döneminden elde edilen yatırım oranları ile oluşturulan portföyler, 01/01/2016 - 31/12/2016 tarihleri arasındaki BİST30 endeksinin getiri ve risk değerleri baz alınarak; getiri değerine, risk değerine ve Sharpe Oranı değerine göre test edilmektedir. Burada öncelikli olarak amaç Markowitz tipi modern portföy yaklaşımı ile kurulan portföylerin geleneksel basit çeşitlendirme yaklaşımı ile kurulan portföyden daha iyi performans sağlayıp sağlamadığını görmektir. Daha sonra ise, hangi veri setine göre yapılan optimizasyondan elde edilen yatırım oranlarının 1 yıl vadeli yatırım tahmininde daha başarılı olduğunu test etmek ve hangi optimizasyon seçeneğinin daha iyi sonuçlar sağladığını incelemektir.

\subsubsection{Optimizasyon Seçeneklerinin Test Edilmesi}

$\mathrm{Bu}$ aşamada geleneksel portföy yaklaşımı baz alınarak yapılan EA yöntemi, modern portföy teorisi baz alınarak uygulanan RKGM, GKRM, DRM ve SOM her bir zaman periyoduna göre kendi içinde incelenecek ve hangi optimizasyon seçeneğinin daha iyi sonuç verdiği gözlemlenecektir.

Tablo 6.'da 01/07/2015 - 31/12/2015 tarihleri arasındaki BIST-30 endeksinin getirilerine uygulanan optimizasyon sonuçlarından elde edilen yatırım oranlarının 01/01/2016 - 31/12/2016 tarihleri arasındaki endeks değerlerine uygulanmasiyla elde edilen sonuç, test edilmektedir. Buna göre en yüksek getirili portföy, RKGM uygulanarak oluşturulan portföyden; en düşük riskli portföy, DRM uygulanarak oluşturulan portföyden; en yüksek Sharpe Oranlı portföy ise RKGM uygulanarak oluşturulan portföyden elde edilmektedir. 
Portföy Optimizasyonunda veri Setlerinin ve Optimizasyon Seçeneklerinin... | URUN, TAŞ, UĞURLU

Tablo 6. 01/07/2015 - 31/12/2015 Tarihleri Arasındaki BİST-30 Endeksinin Getirilerine Uygulanan Optimizasyon Sonuçlarından Elde Edilen Yatırım Oranlarının 01/01/2016 - 31/12/2016 Tarihleri Arasındaki Endeks Değerlerine Uygulanması

\begin{tabular}{|c|l|r|r|r|r|}
\hline & \multicolumn{1}{|l|}{ EA } & \multicolumn{1}{c|}{ RKGM } & \multicolumn{1}{c|}{ GKRM } & \multicolumn{1}{c|}{ DRM } & \multicolumn{1}{c|}{ SOM } \\
\hline$\mu$ & 0.00078 & 0.00112 & 0.00052 & 0.00059 & 0.00104 \\
\hline$\sigma$ & 0.01289 & 0.01589 & 0.01193 & 0.01121 & 0.01466 \\
\hline S.O. & 0.04049 & 0.05902 & 0.02133 & 0.02902 & 0.05332 \\
\hline
\end{tabular}

Kaynak: Yazarlar tarafindan oluşturulmuştur.

Tablo 7.'de 01/01/2015 - 31/12/2015 tarihleri arasındaki BİST-30 endeksinin getirilerine uygulanan optimizasyon sonuçlarından elde edilen yatırım oranlarının 01/01/2016 - 31/12/2016 tarihleri arasındaki endeks değerlerine uygulanmasıyla elde edilen sonuç, test edilmektedir. Buna göre en yüksek getirili portföy, RKGM uygulanarak oluşturulan portföyden; en düşük riskli portföy, DRM uygulanarak oluşturulan portföyden; en yüksek Sharpe Oranlı portföy ise RKGM uygulanarak oluşturulan portföyden elde edilmektedir.

Tablo 7. 01/01/2015 - 31/12/2015 Tarihleri Arasındaki BIST T-30 Endeksinin

Getirilerine Uygulanan Optimizasyon Sonuçlarından Elde Edilen Yatırım Oranlarının 01/01/2016 - 31/12/2016 Tarihleri Arasındaki Endeks Değerlerine Uygulanması

\begin{tabular}{|l|c|c|c|c|c|}
\hline & EA & RKGM & GKRM & DRM & SOM \\
\hline$\mu$ & 0.00078 & 0.00103 & 0.00073 & 0.00067 & 0.00098 \\
\hline$\Sigma$ & 0.01289 & 0.01305 & 0.01164 & 0.01127 & 0.01367 \\
\hline S.O. & 0.04049 & 0.05881 & 0.04053 & 0.03618 & 0.05242 \\
\hline
\end{tabular}

Kaynak: Yazarlar tarafindan oluşturulmuştur.

Tablo 8.'de 01/01/2014 - 31/12/2015 tarihleri arasındaki BİST-30 endeksinin getirilerine uygulanan optimizasyon sonuçlarından elde edilen yatırım oranlarının 01/01/2016 - 31/12/2016 tarihleri arasındaki endeks değerlerine uygulanmasıyla elde edilen sonuç, test edilmektedir. Buna göre en yüksek getirili portföy, RKGM uygulanarak oluşturulan portföyden; en düşük riskli portföy, GKRM uygulanarak oluşturulan portföyden; en yüksek Sharpe Oranlı portföy ise RKGM uygulanarak oluşturulan portföyden elde edilmektedir. 
Tablo 8. 01/01/2014 - 31/12/2015 Tarihleri Arasındaki BIST-30 Endeksinin

Getirilerine Uygulanan Optimizasyon Sonuçlarından Elde Edilen Yatırım Oranlarının 01/01/2016 - 31/12/2016 Tarihleri Arasındaki Endeks Değerlerine Uygulanması

\begin{tabular}{|l|c|c|c|c|c|}
\hline & EA & RKGM & GKRM & DRM & SOM \\
\hline$\mu$ & 0.00078 & 0.00100 & 0.00071 & 0.00065 & 0.00099 \\
\hline$\Sigma$ & 0.01289 & 0.01270 & 0.01143 & 0.01154 & 0.01263 \\
\hline S.O. & 0.04049 & 0.05836 & 0.03880 & 0.03329 & 0.05737 \\
\hline
\end{tabular}

Kaynak: Yazarlar tarafindan oluşturulmuştur.

Tablo 9.'da 01/01/2013 - 31/12/2015 tarihleri arasındaki BISST-30 endeksinin getirilerine uygulanan optimizasyon sonuçlarının elde edilen yatırım oranları 01/01/2016 - 31/12/2016 tarihleri arasındaki endeks değerlerine uygulanmasıyla elde edilen sonuç test edilmektedir. Buna göre en yüksek getirili portföy, RKGM uygulanarak oluşturulan portföyden; en düşük riskli portföy, DRM uygulanarak oluşturulan portföyden; en yüksek Sharpe Oranlı portföy ise EA uygulanarak oluşturulan portföyden elde edilmektedir.

Tablo 9. 01/01/2013 - 31/12/2015 Tarihleri Arasındaki BİST-30 Endeksinin

Getirilerine Uygulanan Optimizasyon Sonuçlarından Elde Edilen Yatırım Oranlarının 01/01/2016 - 31/12/2016 Tarihleri Arasındaki Endeks Değerlerine Uygulanması

\begin{tabular}{|l|c|c|c|c|c|}
\hline & EA & RKGM & GKRM & DRM & SOM \\
\hline$\mu$ & 0.00078 & 0.00080 & 0.00068 & 0.00068 & 0.00064 \\
\hline$\Sigma$ & 0.01289 & 0.01370 & 0.01125 & 0.01124 & 0.01455 \\
\hline S.O. & 0.04049 & 0.03929 & 0.03700 & 0.03694 & 0.02607 \\
\hline
\end{tabular}

Kaynak: Yazarlar tarafindan oluşturulmuştur.

\subsubsection{Veri Dönemlerinin Test Edilmesi}

$\mathrm{Bu}$ bölümde, 4 farklı, ama birbirini kapsayan tarihlerdeki, veri setine uygulanan optimizasyonlardan elde edilen portföyler, 01/01/2016 - 31/12/2016 tarihleri arasındaki endeks değerlerine göre test edilecektir. Her optimizasyon seçeneğine göre hangi veri döneminin daha iyi sonuç verdiği gözlemlenecektir.

Tablo 10.'da BİST-30 endeksinin 4 farklı veri setine uygulanan risk kısitlı getiri maksimizasyonundan elde edilen yatırım oranları 01/01/2016 - 31/12/2016 tarihleri arasındaki BİST-30 endeks değerlerine uygulanmıştır. Buna göre, ortalama getiri bakımından incelendiğinde en iyi getirili portföy sırasıyla 6 aylık, 1 yıllık, 2 yıllık ve 3 
y1llık verilere uygulanan risk kısitlı getiri maksimizasyonundan elde edilmektedir. Sharpe Oranı bakımından incelendiğinde en yüksek Sharpe Oranına sahip portföy sırasıyla 6 aylık, 1 yıllık, 2 yıllık ve 3 yıllık getirilere uygulanan risk kısitlı getiri maksimizasyonundan elde edilmektedir. Yani risk kisttl getiri maksimizasyonu yöntemiyle getiri maksimize edilmeye çalışlacaksa veri setinin daha kısa süreli alınması gerekmektedir. Optimizasyonun amacı getiri maksimizasyonu üzerine olduğu için risk değerlerinde bir inceleme yapılmasına gerek yoktur.

Tablo 10. Risk Kısıtlı Getiri Maksimizasyonuna Göre Elde Edilen Yatırım Oranlarının 01/01/2016 - 31/12/2016 Tarihleri Arasındaki BİST-30 Endeks Değerlerine Uygulanması

\begin{tabular}{|l|c|c|c|c|}
\cline { 2 - 5 } \multicolumn{1}{c|}{} & 6 Aylik & 1 Y1ll1k & 2 Y1ll1k & 3 Y 11 lik \\
\hline$\mu$ & 0.00120 & 0.00103 & 0.00100 & 0.00080 \\
\hline$\Sigma$ & 0.01589 & 0.01305 & 0.01270 & 0.01370 \\
\hline S.O. & 0.05902 & 0.05881 & 0.05836 & 0.03929 \\
\hline
\end{tabular}

Kaynak: Yazarlar tarafindan oluşturulmuştur.

Tablo 11.'de BİST-30 endeksinin 4 farklı veri setine uygulanan getiri kisitlı risk minimizasyonundan elde edilen yatırım oranları 01/01/2016 - 31/12/2016 tarihleri arasındaki BİST-30 endeks değerlerine uygulanmıştır. Buna göre risk değeri açısından bakıldığında en düşük riskli portföy sırasıyla 3 yıllık, 2 yıllık, 1 yıllık ve 6 aylık verilere uygulanan getiri kıstll risk minimizasyonundan elde edilmektedir. Yani getiri kisitlı risk minimizasyonu yöntemiyle risk minimize edilmeye çalışılacaksa veri setinin daha uzun süreli alınması gerekmektedir. Optimizasyonun amacı risk minimizasyonu üzerine olduğu için getiri ve Sharpe Oranı değerlerinde bir inceleme yapılmasına gerek yoktur.

Tablo 11. Getiri Kısıtlı Risk Minimizasyonuna Göre Elde Edilen Yatırım Oranlarının 01/01/2016 - 31/12/2016 Tarihleri Arasındaki BİST-30 Endeks Değerlerine Uygulanması

\begin{tabular}{|l|c|c|c|c|}
\cline { 2 - 5 } \multicolumn{1}{c|}{} & 6 Aylik & 1 Y1llik & 2 Yillik & 3 Y1llik \\
\hline$\mu$ & 0.00052 & 0.00073 & 0.00071 & 0.00068 \\
\hline$\Sigma$ & 0.01193 & 0.01164 & 0.01143 & 0.01125 \\
\hline S.O. & 0.02133 & 0.04053 & 0.03880 & 0.03700 \\
\hline
\end{tabular}

Kaynak: Yazarlar tarafindan oluşturulmuştur.

Tablo 12.'de BİST-30 endeksinin 4 farklı veri setine uygulanan direkt risk minimizasyonundan elde edilen yatırım oranları 01/01/2016 - 31/12/2016 tarihleri arasındaki BİST-30 endeks değerlerine uygulanmıştır. Buna göre risk değeri açısından bakıldığında en düşük riskli portföy sırasıyla 6 aylık, 3 yıllık, 1 yıllık ve 2 yıllık verilere uygulanan direkt risk minimizasyonundan elde edilmektedir. Burada en düşük riskli 
URUN, TAŞ, UĞURLU| The Comparison of the Datasets and the Optimization Alternatives in the Portfolio...

portföyü en kısa süreli olan veri seti sağlamaktadır. Tam sırasıyla olmasa da veri seti uzadıkça risk değeri yükselmektedir. Burada da optimizasyonun amacı risk minimizasyonu üzerine olduğu için getiri ve Sharpe Oranı değerlerinde bir inceleme yapılmasina gerek yoktur.

Tablo 12. Direkt Risk Minimizasyonuna Göre Elde Edilen Yatırım Oranlarının 01/01/2016 - 31/12/2016 Tarihleri Arasındaki BİST-30 Endeks Değerlerine Uygulanması

\begin{tabular}{|l|c|c|c|c|}
\cline { 2 - 5 } \multicolumn{1}{c|}{} & 6 Aylik & 1 Y1llik & 2 Y1ll1k & 3 Y1ll1k \\
\hline$\mu$ & 0.00059 & 0.00067 & 0.00065 & 0.00068 \\
\hline$\Sigma$ & 0.01121 & 0.01127 & 0.01154 & 0.01124 \\
\hline S.O. & 0.02902 & 0.03618 & 0.03329 & 0.03694 \\
\hline
\end{tabular}

Kaynak: Yazarlar tarafindan oluşturulmuştur.

Tablo 13.'te BİST-30 endeksinin 4 farklı veri setine uygulanan Sharpe Oranı maksimizasyonundan elde edilen yatırm oranları 01/01/2016 - 31/12/2016 tarihleri arasındaki BIST-30 endeks değerlerine uygulanmıştır. Buna göre, ortalama getiri bakımından incelendiğinde en iyi getirili portföy sırasıyla 6 aylık, 2 yıllık, 1 yıllık ve 3 yıllık verilere uygulanan Sharpe Oranı maksimizasyonundan elde edilmektedir. Risk değeri bakımından incelendiğinde en düşük riskli portföy sırasıyla 2 yıllık, 1 yıllık, 3 yıllık ve 6 aylık verilere uygulanan Sharpe Oranı maksimizasyonundan elde edilmektedir. Sharpe Oranı bakımından incelendiğinde en yüksek Sharpe Oranına sahip portföy sirasıyla 2 yıllık, 6 aylık, 1 yıllık ve 3 yıllık getirilere uygulanan Sharpe Oranı maksimizasyonundan elde edilmektedir. Sharpe Oranı maksimizasyonunda getiri, veri seti ne kadar kısaysa o derece başarılı sonuçlar verse de risk değeri açısından incelendiğinde, veri seti açısından herhangi bir ilişki söz konusu değildir. Sharpe Oranı açısından bir inceleme yapıldığında ise en uzun süreli veri seti en kötü Sharpe Oranı değerini vermektedir.

Tablo 13. Sharpe Oranı Maksimizasyonuna Göre Elde Edilen Yatırım Oranlarının 01/01/2016 - 31/12/2016 Tarihleri Arasındaki BİST-30 Endeks Değerlerine Uygulanması

\begin{tabular}{|l|c|c|c|c|}
\cline { 2 - 5 } \multicolumn{1}{c|}{} & 6 Aylik & 1 Y1ll1k & 2 Y1llk & 3 Y1llk \\
\hline$\mu$ & 0.00104 & 0.00098 & 0.00099 & 0.00064 \\
\hline$\Sigma$ & 0.01466 & 0.01367 & 0.01263 & 0.01455 \\
\hline S.O. & 0.05332 & 0.05242 & 0.05737 & 0.02607 \\
\hline
\end{tabular}

Kaynak: Yazarlar tarafindan oluşturulmuştur. 


\section{SONUC}

$\mathrm{Bu}$ çalışmada iki farklı durumun incelendiği görülmektedir. Birinci durumda, yatırımcının amaç fonksiyonuna göre hangi optimizasyon seçeneğinin kullanılması gerektiği durumu gözlemlenmiştir. Getirisini maksimize etmek isteyen bir yatırımcı için dört veri setinde de en iyi sonucu, risk kısıtlı getiri maksimizasyonu ile oluşturulan portföy sağlarken; en kötü sonucu, getiri kısıtlı risk minimizasyonu ile oluşturulan portföyler vermektedir. Riskini minimize etmek isteyen bir yatırımcı için dört veri setinde de en iyi sonucu direkt risk minimizasyonu ve getiri kısitl risk minimizasyonu ile oluşturulan portföyler sağlamaktadır. Sharpe Oranını maksimize etmek, yani bir birim risk başına elde edilecek getiriyi maksimize etmek isteyen yatırımcı tipi, için genellikle en iyi sonucu, risk kısıtlı getiri maksimizasyonu ile oluşturulan portföy sağlamaktadır.

İkinci durumda ise, yatırımcı tipine göre hangi veri setinin kullanılması gerektiği gözlemlenmiştir. Belirli bir getiri düzeyinde, düşük riskli bir portföy oluşturmak isteyen bir yatırımcı, kullanacağı veri setini, uzun süreli tutmalıdır. Veri seti, kademeli olarak kısaldığında, oluşacak portföyün riski de kademeli olarak artmaktadır. Direkt olarak riski minimize edip, sonrasında bu kısıt altında yüksek getirili ve yüksek Sharpe Oranlı bir portföy oluşturmak isteyen yatırımcı da uzun süreli bir veri setini tercih etmelidir. En uzun süreli veri seti kullanılarak elde edilen portföyün getiri ve Sharpe Oranı değeri en büyük iken, en kısa süreli veri seti kullanılarak elde edilen portföyün getiri ve Sharpe Oranı değeri en küçüktür. Belirli bir risk düzeyinde yüksek getirili ve yüksek Sharpe Oranına sahip bir portföy oluşturmak isteyen bir yatırımcı kullanacağı veri setini kısa vadeli seçmelidir. Veri seti kademeli olarak uzadığında oluşacak portföyün getiri değeri ve Sharpe Oranı da kademeli olarak azalmaktadır. Direkt olarak Sharpe Oranını maksimize edip sonrasında bu kısıt altında, yüksek getirili portföy oluşturmak isteyen yatırımcı ise kısa süreli veri setini kullanmalıdır. En kısa süreli veri seti kullanılarak elde edilen portföyün getiri değeri, en yüksek iken; en uzun süreli veri seti ile oluşturulan portföyün getiri değeri ise en düşüktür.

Çalışmanın sonuçlarının Campbell vd. (2001)'den bir miktar farklılaştığı söylenebilir. Campbell $v d$. (2001)'nin, ABD piyasasındaki hisse senedi ve tahvilleri ele alarak yaptığı çalışmada optimal portföyü elde etmek için yatırım süresinin uzunluğunun oldukça büyük bir önem teşkil ettiğini belirtmelerine rağmen bu çalışmada kullanılan veri setinin her durumda uzun tutulmasina gerek olmadığı, aksine bazı durumlarda kısa süreli veri setinin kullanılması gerektiği gösterilmiştir. Buna ek olarak ABD gibi gelişmiş ekonomilerde sabit bir sonuç mevcutken, Türkiye gibi ekonomisi sürekli değiş̧kenlik gösteren ülkelerde sonuçların değiş̧en olduğu düşünülmektedir. 
Korhan (2013), yaptığı çalışmada kısa süreli yatırımlar için daha uzun süreli veri setinin kullanılmasını, uzun vadeli yatırımlar için ise daha kısa süreli veri setinin kullanılmasını önermiştir. Ancak bizim makalemizde bir yıl süreli bir yatırım için getiri değeri ve Sharpe Oranı baz alınarak bakıldığında daha kısa süreli veri setinin kullanılması gerektiği, risk değeri baz alınarak bakıldığında ise daha uzun süreli veri setinin kullanılması gerektiği tespit edilmiştir.

Gelecek çalışmalarda farklı veri dönemleri ve farklı ülke endeksleri ile yapılacak çalışmalar da incelenerek, model sonuçları daha güvenilir hale getirilebilir.

\section{KAYNAKÇA}

Akçayır, Ö., B. Doğan, Y. Demir (2014), "Elton-Gruber Kısıtlı Markowitz Kuadratik Programlama ile Portföy Optimizasyonu: BİST-50 Üzerine Bir Uygulama”, Süleyman Demirel Üniversitesi İktisadi ve İdari Bilimler Fakültesi Dergisi, 13(3), 333-352.

Bekçioğlu, S. (1984), Portföy Yaklaşımları ve Markowitz Portföy Yaklaşımının Türk Hisse Senedi Piyasasina Uygulanmast, Ankara: ???.

Berk, N. (1995), Finansal Yönetim, İstanbul: Türkmen Kitabevi.

Bolak, M. (1998), Sermaye Piyasası Menkul Kiymetler ve Portföy Analiz, İstanbul: Beta Basım Yayım Dağıtım.

Campbell, R., R. Huisman, K. Koedijk (2001), "Optimal Portfolio Selection in a Value-at-Risk Framework", Journal of Banking \& Finance, 25(9), 1789-1804.

Çetin, A. C. (2007), "Markowitz Kuadratik Programlama ile Optimal Portföy Seçimi", Süleyman Demirel Üniversitesi İktisadi İdari Bilimler Fakültesi Dergisi, 12(1), 63-81.

Çetin, A. C. (2009), "Küresel Finansal Krizde Portföy Optimizasyonu ve IMKB Uygulaması", Süleyman Demirel Üniversitesi Sosyal Bilimler Enstitüsü Dergisi, 1(9), 93-114.

DeMiguel, V., L. Garlappi, R. Uppal (2009), "Optimal Versus Naive Diversification: How Inefficient is the 1/N Portfolio Strategy?", The Review of Financial Studies, 22(5), 1915-1953.

Elton, E.J., M.J. Gruber (1995), Modern Portfolio Theory and Investment Analysis, New York: Wiley.

Francis, J. C. (1976), Investment: Analysis and Management, New York: Mc. Graw - Hill Book Company.

Güran, C.B., O. Taş (2015), "Making Second Order Stochastic Dominance Inefficient Mean Variance Portfolio Efficient: Application in Turkish BIST-30 Index", Iktisat Işletme ve Finans, 30(348), 69-94.

Kardiyen, F. (2008), "Portföy Optimizasyonunda Ortalama Mutlak Sapma Modeli ve Markowitz Modelinin Kullanımı ve IMKB Verilerine Uygulanması", Süleyman Demirel Üniversitesi İktisadi ve İdari Bilimler Fakültesi Dergisi, 13(2), 335-350. 
Korhan, E. (2013), Çok Dönemli Markowitz Ortalama Varyans Portföy Optimizasyonu ile En Uygun Yatırım Vadelerinin Belirlenmesi: BİST-30 Endeks Hisseleri Üzerine Bir Uygulama, Yüksek lisans tezi, Pamukkale Üniversitesi Sosyal Bilimler Enstitüsü.

Markowitz, H. M. (1952), "Portfolio Selection”, The Journal of Finance, 7(1), 77-91.

Nogales, J.F., V. DeMiguel, L. Garlappi, R. Uppal (2009), “A Generalized Approach to Portfolio Optimization: Improving Performance by Constraining Portfolio Norms", Management Science, 55(5), 798-812.

Rubinstein, M. (2002), "Markowitz's Portfolio Selection: A Fifty-year Reprospective”, The Journal of Finance, 58(3), 1041-1045.

Sharpe W.F. (1978), Investments, Englewood Cliffs, New Jersey: Prentice-Hall.

Tas, O., F.M. Barijough, U. Ugurlu (2015), "A Test of Second-Order Stochastic Dominance With Different Weighting Methods: Evidence from BIST-30 and DJIA”, Journal of Business, Economics and Finance, 4(4), 723-731.

Üstünel, İ.E. (2000), Durağan Portföy Analizi ve IMKB Verilerine Uygulanmast, Ankara: İstanbul Menkul Kiymetler Borsası. 